\title{
STUDIES ON THE CHEMOTHERAPY OF THE HUMAN MALARIAS. IX. EFFECT OF PAMAQUINE ON THE BLOOD CELLS OF MAN 1, 2, 8
}

\author{
BY DAVID P. EARLE, JR., FREDERICK S. BIGELOW,4 CHARLES G. ZUBROD,4 \\ AND CHARLES A. KANE * \\ (From the Department of Medicine, New York University College of Medicine, and the \\ Research Service, Third [New York University] Medical Division, \\ Goldwater Memorial Hospital, New York City)
}

(Received for publication March 12, 1947)

Pamaquine (6-methoxy-8-amino [N-diethylaminoisopentyl] quinoline) is recognized to be a potentially dangerous drug. However, a definitive appraisal of its hazard had not been achieved at a time when the further exploration of the antimalarial activity of the 8-aminoquinolines was considered advisable. Pamaquine toxicity can involve the gastro-intestinal tract, the central nervous system, and the circulating blood. Symptoms referable to the gastro-intestinal tract and the central nervous system may be annoying, but there is no evidence that they constitute a hazard to life or persist beyond the termination of therapy. Effects on the blood do constitute a serious hazard and are considered in this paper.

\section{MATERIALS AND METHODS}

Most of the patients utilized as subjects either were having malaria at the time of the observations or had had the disease from one to six weeks previously. None of the patients had malaria long enough to be considered likely subjects for the development of blackwater fever. Most subjects were suffering from asymptomatic neurosyphilis and many had received prior antiluetic therapy.

1 The work described in this paper was done under a contract, recommended by the Committee on Medical Research, between the Office of Scientific Research and Development and New York University.

$2 \mathrm{~A}$ portion of this work was presented at the meetings of the Federation of the American Societies for Experimental Biology, March 11-15, 1946, Federation Proc., 1946, 5, 176 and 217.

8 The authors express their thanks to the Malaria Study Section of the National Institute of Health for editorial assistance and for arrangements in regard to the publication of this paper. They are also grateful to the Abbott Laboratories, E. I. du Pont de Nemours and Company, Inc., E. R. Squibb and Sons, Eli Lilly and Company, Sharp and Dohme, and Wyeth, Inc., for contributing toward the publication costs.

4 Captain, MC, AUS.
However, whenever indicated, sufficient data were collected in normal subjects.

Plasma pamaquine levels were estimated by the method of Brodie, Taggart and Udenfriend (1). A modification of the method of Horecker and Brackett (2) was utilized for the measurement of methemoglobin.

\section{Special blood studies:}

(a) Isoagglutinins. Fresh suspensions of group A; B, and $O$ erythrocytes were prepared each test day. The same donors were used throughout the study. The cells were washed once with sterile physiological saline and a 2 per cent solution in saline prepared. Test serum was obtained by allowing the whole blood to clot and centrifuging the sample. Half milliliter samples of the cell suspensions were added to $0.5 \mathrm{ml}$. of serial dilutions of the test serum in small glass test-tubes. The tubes were placed in a water-bath at $37^{\circ} \mathrm{C}$. for three hours. The tubes were then removed, agitated gently, and observed for macroscopic agglutination in a well-lighted, white viewing box. Agglutination was recorded on a scale of 1 to 4 plus. The final titer was taken as the greatest serum dilution that caused agglutination.

(b) Serum hemolysins. The tubes containing the group $O$ erythrocytes described in the isoagglutinin technique were examined for the presence of hemolysis.

(c) Cold hemagglutinins. Titers of cold hemagglutinins were measured by a technique based on that of Favour (3). Indicator cells were derived from a group $O$ donor whose serum contained no cold hemagglutinins. The titers were recorded as the maximum dilution of saline plus cell suspension at which visible agglutination occurred after 18 hours at $4^{\circ} \mathrm{C}$.

(d) Autoagglutination was looked for by microscopic examination of a small drop of freshly drawn blood in a large drop of saline. If cold hemagglutinins were present, the slide was kept warm until the examination was completed.

(e) Fragility of erythrocytes to hypotonic saline. A 2 per cent suspension of erythrocytes in sterile physiological saline was prepared from blood containing one drop of saturated potassium oxalate per $5 \mathrm{ml}$. of blood. 0.5 $\mathrm{ml}$. of the cell suspension was added as soon as possible to $2 \mathrm{ml}$. each of 0.9 per cent sodium chloride (control), to distilled water (total hemoglobin), and to a series of sodium chloride dilutions usually ranging from 0.48 per 
cent to 0.30 per cent in steps of 0.02 per cent. The tubes were placed in a water-bath at $37^{\circ} \mathrm{C}$. for two hours. The samples were then centrifuged at slow speed for ten minutes. The hemoglobin content of the supernatant fluids was determined on a Coleman Junior Colorimeter. The galvanometer was set at 100 per cent transmission with the supernatant fluid from the 0.9 per cent sodium chloride tube. All readings in each test were made in the same cuvette. The results were expressed in per cent hemolysis at the various saline dilutions uncorrected for the addition of the cell suspension. The highest sodium chloride concentration resulting in 5 per cent hemolysis was arbitrarily chosen as the point of beginning hemolysis.

(f) The resistance of erythrocytes to mechanical trauma was measured by the technique of Shen, Castle and Fleming (4).

\section{Section I}

\section{METHEMOGLOBINEMIA DUE TO PAMAQUINE}

It is well known that methemoglobinemia is a common result of pamaquine therapy $(5,6)$. The present study is concerned with the degree of methemoglobinemia achieved on various regimens of pamaquine, alone and in combination with quinacrine or quinine. More detailed studies of this phenomenon in relation to blood pigment metabolism will be reported elsewhere.

Observations. Serial methemoglobin determinations were made in patients given various doses of pamaquine, alone or in combination with quinacrine or quinine. These data are summarized in Table I. Methemoglobinemia gradually increases on serial dosage with pamaquine and achieves a fairly stable level by the fifth or sixth day of treatment. For this reason only subjects who had received pamaquine for five or more days are included in the data presented in Table $\mathrm{I}$. The methemoglobins recorded in the table are the maximum values achieved. Although there is

\section{TABLE I}

Methemoglobin per cent in patients after five to seven days of various pamaquine regimens

\begin{tabular}{l|c|c|c|c}
\hline \hline \multicolumn{1}{|c|}{ Treatment group } & $\begin{array}{c}\text { Num- } \\
\text { ber } \\
\text { of } \\
\text { sub- } \\
\text { jects }\end{array}$ & $\begin{array}{c}\text { Mean } \\
\text { per } \\
\text { cent } \\
\text { met- } \\
\text { hemo- } \\
\text { globin }\end{array}$ & $\begin{array}{c}\text { Stand- } \\
\text { ard } \\
\text { devia- } \\
\text { tion }\end{array}$ & $\begin{array}{c}\text { Range } \\
\text { per cent } \\
\text { methemo- } \\
\text { globin }\end{array}$ \\
\hline Pamaquine, 90 mgm. daily & 24 & 12.2 & 7.0 & $0.9-28.7$ \\
Pamaquine, 60 mgm. daily & 13 & 8.9 & 4.5 & $1.9-20.8$ \\
Pamaquine, 30 mgm. daily & 29 & 4.4 & 2.4 & $0.7-10.0$ \\
Pamaquine, 30 mgm. daily, & 6 & 12.2 & 4.6 & $6.0-19.3$ \\
\hline
\end{tabular}

marked variation in methemoglobinemia among individuals on any given regimen, the mean value for each group is proportional to the daily dose of pamaquine, except in the group that also received quinacrine. The mean methemoglobin value achieved by this group on $30 \mathrm{mgm}$. of pamaquine daily is equal to that of the subjects given $90 \mathrm{mgm}$. of pamaquine daily but without quinacrine.

Approximately half of each of the first three groups recorded in Table I received 2 grams of quinine daily along with the pamaquine. There was no statistically. significant difference between the methemoglobin values achieved by those given quinine and those not given quinine. Very high concentrations of pamaquine, far greater than those achieved in the plasma on therapeutic dosage, are required to produce methemoglobin in erythrocytes in vitro. Probably for this reason there was only a rough correlation between methemoglobinemia and plasma drug levels among the patients given pamaquine. However, it was noted that the occasional individual who developed excessively high plasma pamaquine levels on low dosage also had relatively high methemoglobin percentages. Cyanosis was noted in most white individuals who had methemoglobin values greater than 10 per cent.

Weakness and intolerance to exercise were prominent among the patients given $90 \mathrm{mgm}$. of pamaquine daily, and were also noted among those given $60 \mathrm{mgm}$. daily. These symptoms were only roughly parallel to the methemoglobin levels and were probably due to some other action of the drug.

\section{Section II}

\section{THE PAMAQUINE HEMOLYTIC REACTION}

Acute hemolytic anemia constitutes the most serious hazard incidental to the administration of pamaquine. A report of 260 such reactions treated in the Gorgas Hospital in 1942 (7) substantiates this view.

A study of hemolytic anemias occurring among patients given pamaquine was undertaken with the hope that the clarification of the mechanism of their production would be of value in the use of pamaquine or of related synthetic compounds. It was also hoped that the collection of the clinical information necessary for the study of the mech- 
anism of the hemolytic phenomena would yield information on premonitory signs and symptoms of the hemolytic event. Should signs or symptoms be uncovered which would permit the early prediction of the probable occurrence of a hemolytic event, then the termination of pamaquine therapy prior to the appearance of frank hemolysis would constitute a further safeguard during the administration of this agent. Unfortunately, no specific premonitory signs were established.

Such a study is conditioned by the fact that hemolytic anemias are observed in only some 5 to 10 per cent of individuals receiving pamaquine. Such a situation is compatible with the view that pamaquine per se is a precipitating factor capable of producing an anemia when certain predisposing factors are present rather than the sole etiological agent. Such predisposing factors might be attributable to prior experience with malaria, or some metabolic defect that causes a diversion from the normal in the metabolism of pamaquine. The latter may result in the production in significant amounts of one or more highly noxious agents which in turn are responsible for the hemolytic episode. The studies reported in this section do not settle this problem, although it is apparent that negroes are more prone to develop acute hemolytic anemia than are white subjects. It is possible that prior quinacrine therapy is also a predisposing factor.
Observations. Hemolytic anemia occurred in seven of 157 patients given pamaquine naphthoate in repeated doses for two to 14 days. The race of each patient who developed hemolytic anemia and the preceding events are summarized in Table II.

Five acute hemolytic anemias occurred in negroes and one in a Chinese. A slowly developing hemolytic anemia occurred in a seventh patient who was white and who received $90 \mathrm{mgm}$. of pamaquine and 2 grams of quinine daily for the treatment of vivax malaria. The plasma pamaquine level and the hemoglobin concentration in relation to pamaquine dosage and onset of symptoms are recorded in Table III. Jaundice, dark urine, or symptoms of acute blood loss were first noted on the third to fifth day of drug administration. A significant loss of hemoglobin was usually noted on the same day as the onset of symptoms. The lowest hemoglobin values occurred one day after the onset of symptoms in four patients, and four and five days after the onset in the other two patients with the acute reaction. Maximal hemoglobin losses varied from 3.7 to 7.9 grams per cent. Serum bilirubin determinations were done during the period of clinical jaundice in three patients. Direct bilirubins were 1.5 , 0.5 , and $0.8 \mathrm{mgm}$. per cent, while the indirect values were $3.5,1.0$, and $1.5 \mathrm{mgm}$. per cent.

Evidence has been adduced (8) to favor the view that concurrent administration of pamaquine

TABLE II

Race and preceding events in hemolytic anemia due to pamaquine

\begin{tabular}{|c|c|c|c|c|c|c|c|c|}
\hline Patient & Race & Species & $\begin{array}{l}\text { Duration of } \\
\text { parasitemia }\end{array}$ & $\begin{array}{c}\text { Interval } \\
\text { between last } \\
\text { parasite and } \\
\text { pamaquine }\end{array}$ & $\begin{array}{l}\text { Typhoid } \\
\text { vaccine } \\
\text { infusions }\end{array}$ & $\begin{array}{c}\text { Prior } \\
\text { therapy }\end{array}$ & $\begin{array}{c}\text { Interval } \\
\text { between end } \\
\text { of prior } \\
\text { therapy and } \\
\text { pamaquine }\end{array}$ & $\begin{array}{c}\text { Fever } \\
\text { during } \\
\text { pamaquine } \\
\text { therapy }\end{array}$ \\
\hline Dal & Negro & $\begin{array}{l}P . \text { malariae } \\
P . \text { falciparum }\end{array}$ & $\begin{array}{c}\text { days } \\
14 \\
23\end{array}$ & $\begin{array}{c}\text { days } \\
10\end{array}$ & $\begin{array}{c}\text { number } \\
8\end{array}$ & quinacrine & $\begin{array}{c}\text { days } \\
3\end{array}$ & yes \\
\hline Fra & Negro & P. falciparum & 5 & 0 & 0 & none & & yes \\
\hline Mat & Negro & $\begin{array}{l}P . \text { falciparum } \\
P . \text { malariae }\end{array}$ & $\begin{array}{l}23 \\
77\end{array}$ & 6 & 8 & quinacrine & $\frac{1}{2}$ & no \\
\hline Mor & Negro & P. falciparum & 31 & 4 & 3 & quinacrine & 0 & no \\
\hline Yat & Negro & P. falciparum & 16 & 7 & 2 & quinacrine & $\frac{1}{2}$ & yes \\
\hline Chi & Chinese & $\begin{array}{l}P . \text { vivax } \\
P . \text { falciparum } \\
P . \text { malariae }\end{array}$ & $\begin{array}{l}10 \\
19 \\
26\end{array}$ & 4 & 3 & quinacrine & $\frac{1}{2}$ & no \\
\hline Fle & White & P. vivax & 4 & 0 & 0 & quinine & 0 & no \\
\hline
\end{tabular}


TABLE III

Hemoglobin loss and onset of. symptoms in hemolytic anemias due to pamaquine

The underscored values for hemoglobin indicate the days on which pamaquine was administered. The day the first symptom was noted is indicated by an asterisk.

\begin{tabular}{|c|c|c|c|c|c|c|c|c|c|c|c|c|c|}
\hline \multirow{2}{*}{ Patient } & \multirow{2}{*}{ 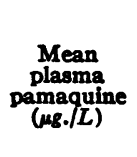 } & \multicolumn{10}{|c|}{$\begin{array}{l}\text { Hemoglobin, grams per cent, on various days subsequent to } \\
\text { initiation of pamaquine therapy }\end{array}$} & \multicolumn{2}{|c|}{ First symptom } \\
\hline & & 1 & 2 & 3 & 4 & 5 & 6 & 7 & 8 & 9 & 12 & Type & $\begin{array}{l}\text { Day of } \\
\text { appear-1 } \\
\text { ance }\end{array}$ \\
\hline Fra & 77 & 13.0 & 14.3 & $12.0 *$ & 9.8 & $6.1 \pm$ & 5.4 & 5.5 & $5.5 t$ & 7.4 & 8.9 & dark urine & 3 \\
\hline Yat & 217 & $=$ & 10.6 & $9.7 *$ & 8.3 & $7.3^{\top}$ & 8.3 & 7.3 & 6.9 & 7.0 & 8.2 & icterus & 3 \\
\hline $\mathrm{Dal}$ & hight & $=$ & 10.3 & 9.1 & $7.4^{*}$ & $5.6 \pm$ & 7.3 & 6.8 & 8.8 & 8.8 & 9.0 & weakness & 4 \\
\hline Mor & high & $\overrightarrow{8.6}$ & $=$ & $=$ & 二* & 2.9 & $4.8 t$ & 6.7 & 6.5 & 6.2 & 8.1 & weakness & 4 \\
\hline Mat & 270 & $\overline{11.3}$ & $\overline{10.0}$ & $\overline{10.3}$ & $\overline{9.1}$ & $\overline{8.1} *$ & 5.9 & 6.9 & 5.9 & 6.2 & 8.0 & icterus & 5 \\
\hline Chi & high & $\overline{-}$ & $\overline{14.0}$ & $\overline{14.0}$ & $\overline{-}$ & $\overline{7.8} *$ & 5.6 & & 6.5 & 6.5 & 8.8 & icterus & 5 \\
\hline Fle & 201 & $\overline{13.5}$ & $\overline{13.7}$ & $\overrightarrow{14.8}$ & $\overline{14.5}$ & $\overline{12.6}$ & 14.0 & 13.9 & 12.7 & $11.9 *$ & 10.3 & weakness & 8 \\
\hline
\end{tabular}

$\dagger$ Level assumed to be greater than $200 \mu \mathrm{g}$. per liter since quinacrine present in body.

$\ddagger$ Transfusion, $500 \mathrm{ml}$. blood.

and quinine causes some slight destruction of hemoglobin which can be detected only by special techniques. The acute hemolytic process under consideration in this paper is obviously quite different. Furthermore, no significant reduction in hemoglobin content is observed in the blood of patients given pamaquine who do not develop acute hemolytic anemia. For instance, frequent estimations of hemoglobin concentration were made in 54 patients receiving pamaquine following the termination of malaria. The mean hemoglobin concentration of these 54 patients was 11.0 grams per cent before and 11.1 grams per cent after four to six days of pamaquine administration. There were five patients among these who lost one or more grams per cent of hemoglobin during pamaquine administration $(1.0,1.1,1.5,1.7$, and 2.0 grams per cent). The situation is in contrast to the six patients with acute hemolytic episodes who lost from 3.7 to 9.9 grams per cent of hemoglobin, the onset of these episodes being three to four days after beginning therapy.

Special studies. An examination of factors that might possibly affect the occurrence of hemolytic anemia during pamaquine administration was undertaken. This included consideration of race, dosage, plasma drug level, prior treatment, methemoglobin, agglutinins and hemolysins, and the resistance of the erythrocytes to hypotonic saline and to mechanical trauma.

No hemolytic anemias occurred among 20 pa- tients (15 negroes, five whites) given 4 to 20 mgm. of pamaquine daily.

Pamaquine was administered in serial dosage in amounts of $30 \mathrm{mgm}$. or more daily to $157 \mathrm{pa}$ tients. The incidence of hemolytic anemia during the administration of pamaquine to these patients according to color, prior quinacrine therapy and plasma pamaquine levels is summarized in Table IV. The most definite correlation achieved by these analyses was that between race and occurrence of hemolytic anemia.

It may be noted that all six acute hemolytic anemias occurred among 76 pigmented individuals, while only one subacute anemia was observed

TABLE IV

Incidence of hemolytic anemia due to pamaquine according to race, quinacrine therapy, and plasma pamaquine level

\begin{tabular}{l|c|c|c|c|c|c}
\hline \hline & \multicolumn{2}{|c|}{$\begin{array}{c}\text { Pigmented } \\
\text { patients }\end{array}$} & \multicolumn{2}{c|}{$\begin{array}{c}\text { White } \\
\text { patients }\end{array}$} & \multicolumn{2}{|c}{$\begin{array}{c}\text { Total } \\
\text { patients }\end{array}$} \\
\cline { 2 - 7 } & $\begin{array}{l}\text { Num- } \\
\text { ber } \\
\text { given } \\
\text { pama- } \\
\text { quine }\end{array}$ & $\begin{array}{c}\text { Hemo- } \\
\text { lytic } \\
\text { ane- } \\
\text { mia }\end{array}$ & $\begin{array}{c}\text { Num- } \\
\text { ber } \\
\text { given } \\
\text { pama- } \\
\text { quine }\end{array}$ & $\begin{array}{c}\text { Hemo- } \\
\text { lytic } \\
\text { ane- } \\
\text { mia }\end{array}$ & $\begin{array}{c}\text { Num- } \\
\text { ber } \\
\text { given } \\
\text { pama- } \\
\text { quine }\end{array}$ & $\begin{array}{c}\text { Hemo- } \\
\text { lytic } \\
\text { ane- } \\
\text { mia }\end{array}$ \\
\hline $\begin{array}{l}\text { Quinacrine } \\
\text { No quinacrine }\end{array}$ & 50 & 5 & 20 & 0 & 70 & 5 \\
$\begin{array}{l}\text { High plasma pama- } \\
\text { quine }\end{array}$ & 51 & 1 & 61 & $1^{*}$ & 87 & 2 \\
$\begin{array}{l}\text { Low plasma pama- } \\
\text { quine }\end{array}$ & 25 & 1 & 37 & 0 & 62 & 1 \\
Total & 76 & 6 & 81 & $1^{*}$ & 157 & 7 \\
\hline
\end{tabular}

* Slowly developing hemolytic anemia. 
among 81 white subjects. In addition, five of the acute anemias occurred among patients who had received prior quinacrine therapy.

No significant relationship between previous or concurrent malaria fever and the incidence of hemolytic anemia could be established for the group as a whole or among the pigmented patients alone.

Serial methemoglobin determinations were made during the administration of pamaquine to 60 patients. Two of these patients developed acute hemolytic anemia, and one, a slowly developing anemia. The methemoglobin in these patients was 7.2 per cent and 19 per cent before the onset of anemia. However, comparable or greater methemoglobinemia (as high as 28 per cent) was observed among the patients who did not develop a hemolytic anemia.

It was thought that malaria might cause changes in the serum or erythrocytes of certain patients that would predispose the cells to rupture to destruction. If such were the case, then pamaquine or some metabolic product could be considered the precipitating agent in the hemolytic reaction. Only one hemolytic anemia occurred among the patients subjected to these special studies. This precludes a definitive answer to the problem.

The following factors were examined:

(a) Isoagglutinins. It has been reported that malaria causes an increase in the titer of isoagglutinins, especially isoagglutinin $a$, and excessively high titers have been reported in two patients with blackwater fever (9). Were this a cause or a predisposing factor in the precipitation of an acute hemolytic anemia, the patient would necessarily belong to Blood Group A or AB. The three patients in the present series who developed an hemolytic anemia during pamaquine administration and who were blood typed, belonged to groups $\mathrm{A}, \mathrm{A}$, and $\mathrm{AB}$. However, no isoagglutinins were found in the serum of the group $A B$ patient during the hemolytic episode. In addition, no evidence of increased isoagglutinin titers was found in 17 patients followed serially throughout the course of their malaria (five vivax, 12 falciparum).

(b) Isohemolysins. No isohemolysins were demonstrable among the patients described above in section $(a)$. (c) Cold hemagglutinins. Serial examination of the cold hemagglutinin titers was performed in 29 patients with malaria. There was an increase in the titer of seven patients, the maximal titer in six of these without histories of recent respiratory infection being 1 to 40 . The seventh patient had a maximum titer during malaria of 1 to 320. However, this patient had recently recovered from an undiagnosed pulmonary infection characterized by slight fever without leucocytosis or cough, and a patch of rales at the right lung base was found on several examinations at the time of the high titer.

Cold hemagglutinins increased to a maximal titer of 1 to 20 in the patient with falciparum malaria who developed hemolytic anemia due to pamaquine administration. However, this increase did not take place until two days after the onset of the anemia. In addition, pamaquine was given to six patients with cold hemagglutinin titers varying from 1 to 20 to 1 to 320 and in none of these was there evidence of an hemolytic anemia.

(d) Autoagglutinins. Autoagglutination, in the absence of cold hemagglutinins, was noted in wet drop preparations in three patients. Two patients were receiving pamaquine but no hemolytic anemia developed in either patient. Patient Fra exhibited autoagglutination only after the onset of his hemolytic anemia.

(e) Fragility of erythrocytes to hypotonic saline. The resistance of erythrocytes to hypotonic saline was examined serially in 25 attacks of $P$. vivax and $P$. falciparum malaria. The data show a moderate increase in hypotonic saline fragility during the initial days of the parasitemia and then a considerable decrease in fragility some seven to 12 days after the onset of parasitemia. Similar results were obtained in nine patients with active malaria during pamaquine administration. These data will be presented in more detail elsewhere.

(f) Resistance of erythrocytes to mechanical trauma. Each "mechanical fragility" (M. F.) was done in duplicate. The mean difference in the per cent hemolysis between the duplicates in 75 tests selected at random is $1.07(\sigma=0.90)$. The mean difference between two tests done on different days in 27 subjects during control periods is 1.64 $(\sigma=1.26)$. The mean M.F. in 38 patients (one 
to six tests per patient) during control periods is $8.0(\sigma=1.95)$ per cent hemolysis.

The effect of malaria on the M.F. of erythrocytes was studied systematically in a series of patients during eight attacks of vivax malaria and 14 attacks of falciparum malaria. The mean M.F. during malarial attacks of varying duration and severity was 8.3 per cent as compared to 8.2 per cent for prior and post malaria control values. No increase in M.F. was noted in patients with malaria which was greater than 2.9 per cent (the mean difference between two consecutive tests in control subjects plus one $\sigma$ ).

The effect of pamaquine alone on the M.F. of 11 patients was also examined. The mean M.F.'s before and during drug administration were 8.4 and 8.8 per cent. There were no individuals with increases greater than 2.9 per cent.

M.F. was studied during the administration of pamaquine to ten patients with active malaria. The mean M.F. of the group during pamaquine administration was 11.4 per cent as compared to the mean control values of 8.0 per cent. In three instances the increases over control values were 6.6, 7.6 and 9.4 per cent, respectively, differences that are statistically significant. The greatest change occurred in a patient who subsequently developed an hemolytic anemia.

However, additional studies on eight patients with vivax malaria who were given large doses of quinine indicate that the M.F. was also significantly increased in this circumstance in four instances. Increased M.F. occurred in three instances when large doses of pamaquine were given to these patients after the malaria was terminated but while quinine therapy was still being given. None of these patients developed hemolytic anemia. These observations indicate that increased M.F. is not useful as a premonitory sign of hemolytic anemia due to pamaquine.

\section{Section III}

\section{GRANULOCYTOPENIA DUE TO PAMAQUINE}

Hasselmann (10) noted one death due to agranulocytosis and "toxic hepatitis" among 103 subjects given 60 to $120 \mathrm{mgm}$. pamaquine hydroiodide daily. However, granulocytopenia had not been noted as a consistent manifestation of pamaquine therapy. During the course of studies on the cura- tive action of pamaquine against vivax malaria, a striking effect on the polymorphonuclear neutrophilic leucocytes was noted. Independently, and at the same time that the present observations were made, Schmidt (11) observed granulocytopenias among monkeys given large doses of pamaquine.

Observations. Eight young adult white volunteers who had been infected by mosquitoes carrying Chesson strain vivax malaria were given 3.0 grams of quinine sulfate over 24 hours, followed by 0.65 gram every eight hours for 15 days, starting on the fourth day of fever. Ninety mgm. pamaquine base daily, in divided doses, were begun two days after the first quinine dose and continued for 14 days.

Daily leucocyte counts were done on each of these eight subjects. One patient, however, is not included in this analysis since pamaquine administration was stopped before the completion of 14 days of therapy. The total daily leucocyte counts for the seven subjects were averaged and presented in Figure 1, in relation to the days of pamaquine administration. This was possible as the curve in each patient was almost identical. A definite rise in leucocyte count occurred in each subject and reached its peak on the sixth or

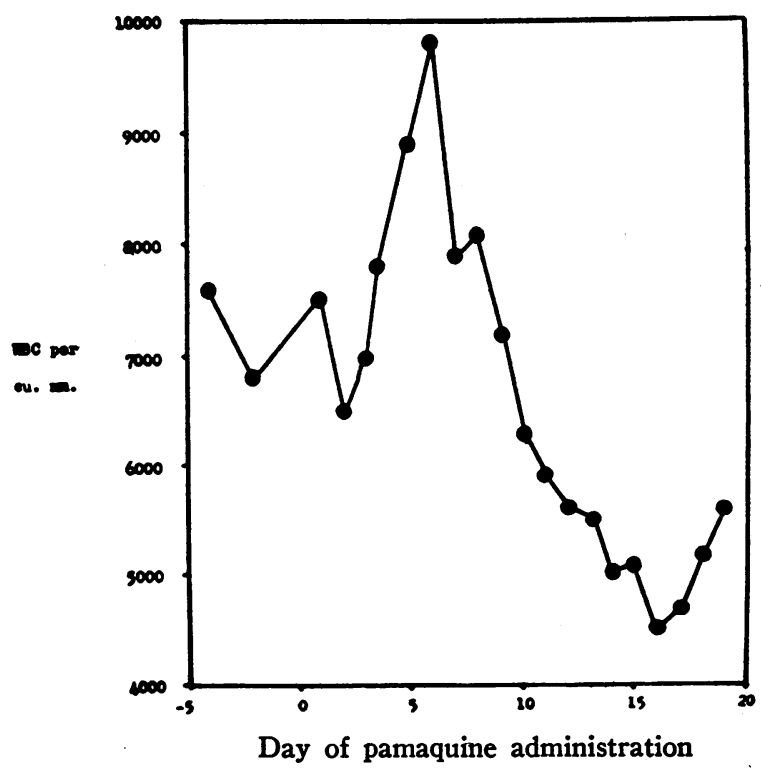

Fig. 1. Mean White Blood Cell Counts (Total) in Seven Subjects Who Received 90 Mgm. of PamaQUiNe Base DaIly for 14 Days 
TABLE V

Effect on the neutrophilic granulocytes of man of various doses of pamaquine administered for 14 days

\begin{tabular}{|c|c|c|c|c|c|}
\hline \multirow[b]{2}{*}{ Treatment group } & \multirow[b]{2}{*}{$\begin{array}{l}\text { Num- } \\
\text { ber } \\
\text { of } \\
\text { sub- } \\
\text { jects }\end{array}$} & \multicolumn{4}{|c|}{$\begin{array}{l}\text { Neutrophilic granulocytes per } \\
\text { cubic millimeter }\end{array}$} \\
\hline & & $\begin{array}{l}\text { Aver- } \\
\text { age } \\
\text { before } \\
\text { pama- } \\
\text { quine }\end{array}$ & $\begin{array}{c}\text { Aver- } \\
\text { age } \\
\text { after } \\
14 \\
\text { days } \\
\text { pama- } \\
\text { quine }\end{array}$ & $\begin{array}{l}\text { Aver- } \\
\text { age } \\
\text { de- } \\
\text { crease }\end{array}$ & $\begin{array}{c}\text { Range of } \\
\text { minimum } \\
\text { counts }\end{array}$ \\
\hline $\begin{array}{l}\text { Pamaquine, } 90 \mathrm{mgm} \text {. daily } \\
\text { Pamaquine, } 60 \mathrm{mgm} \text {. daily } \\
\text { Pamaquine, } 30 \mathrm{mgm} \text {. daily } \\
\text { Pamaquine, } 30 \mathrm{mgm} \text {. daily, } \\
\text { plus quinacrine }\end{array}$ & $\begin{array}{r}12 \\
4 \\
11 \\
6\end{array}$ & $\begin{array}{l}4762 \\
3878 \\
4650 \\
5093\end{array}$ & $\begin{array}{l}1714 \\
2920 \\
2890 \\
1493\end{array}$ & $\begin{array}{r}3048 \\
958 \\
1950 \\
3600\end{array}$ & $\begin{array}{r}900-3500 \\
1590-3840 \\
1600-4600 \\
1150-2100\end{array}$ \\
\hline
\end{tabular}

seventh day of pamaquine administration. There was then a gradual fall in count which reached a minimum 16 to 17 days after beginning pamaquine dosage, or two to three days after stopping the drug. Approximately five days after stopping pamaquine, the leucocytes apparently began a slow return toward normal numbers. The changes in leucocyte counts were entirely due to variations in the numbers of neutrophilic polymorphonuclear leucocytes. No morphological changes were observed in the leucocytes. The remaining neutrophilic polymorphonuclear leucocytes showed a younger distribution than normal. Platelets were not counted, but appeared to be abundant in stained blood films. No sore throats or other infections were noted among the subjects during the period of granulocytopenia. The effect of various dosages of pamaquine is summarized in Table $\mathrm{V}$. Further studies showed that neither concurrent quinine therapy nor a preceding malaria was necessary for the granulocytopenia observed during pamaquine administration, although quinacrine apparently potentiates the effect. Compare groups 3 and 4 in Table V.

\section{GENERAL DISCUSSION}

The adverse reactions due to pamaquine which are referable to the blood include the production of methemoglobin, the occurrence of hemolytic anemia, and of neutrophilic granulocytopenia. The occurrence of methemoglobin, per se, is rarely a deterrent to the continued administration of pamaquine since it is unusual, even with high doses, for the oxygen capacity of the blood to be reduced sufficiently to precipitate respiratory diseases. Granulocytopenia represents a potential danger to life, but this reaction has not been noted at doses ordinarily used in therapy. Furthermore, when it occurs, the process is not precipitous and rapidly disappears on cessation of dosage.

It would appear that the hemolytic reaction is the most seriously toxic hazard of pamaquine. This judgment is based upon the information available in the literature as well as on the experience of this service with the administration of pamaquine under close clinical supervision to some 160 patients over a period of two years.

The mechanisms whereby pamaquine exerts its effects on the formed elements of the blood have not been established by these studies. However, in the instances of the acute hemolytic anemias, it appears that pamaquine or, more likely, one of its metabolic products, acts as a precipitating factor capable of producing hemolysis when certain predisposing factors are present. This hypothesis is based on the observations that acute hemolytic anemia occurs in only a small proportion of individuals given pamaquine, that race has an effect on the incidence of the hemolytic episodes, and that there is probably no correlation between plasma pamaquine levels and the hemolytic reaction.

In contrast, methemoglobinemia and granulocytic neutropenia regularly result when pamaquine is given in sufficient dosage, both phenomena are potentiated by quinacrine, which increases plasma pamaquine levels (12), and both phenomena appear to be roughly correlated with plasma pamaquine levels.

\section{SUMMARY}

1. The administration of pamaquine results in methemoglobinemia which is roughly proportional to dosage. The effect is potentiated by concurrent quinacrine treatment.

2. Some $\mathbf{5}$ to $\mathbf{1 0}$ per cent of non-Caucasian patients given pamaquine develop acute hemolytic anemia on the third to fifth day of dosage. The incidence of hemolytic anemia among white patients given pamaquine is much lower.

3. The administration of $90 \mathrm{mgm}$. of pamaquine for 14 days results in a significant reduction of mature neutrophilic granulocytes. Pamaquine in daily doses of $30 \mathrm{mgm}$. does not have this effect unless quinacrine is also administered. 


\section{CASE REPORTS}

1. Acute hemolytic anemia due to pamaquine. One patient (Fra), a negro, who had not received prior quinacrine therapy, was studied more completely before, during, and after his hemolytic episode than were the others. This patient was born in Puerto Rico, moved to Panama in his youth, and to this country about 15 years ago, but had no history of previous malaria.

During the period of pamaquine administration this patient had active falciparum malaria with considerable fever each day and a parasite density in the peripheral blood as high as 233,000 per cu. $\mathrm{mm}$. Pamaquine dosage was $5 \mathrm{mgm}$. (free base) every four hours, the mean plasma drug level during therapy being $77 \mu \mathrm{g}$. per liter.

The first clinical sign of hemolysis occurred when the patient voided deep red urine 56 hours after the first dose of pamaquine. The color of the urine during the next several days varied from dark brown to black. Plasma samples obtained during this period were also brown in color. The signs and symptoms observed during the hemolytic episode were indistinguishable from those usually accompanying blackwater fever, although there was no anuria or severe collapse.

The laboratory observations reflected the changes usually associated with acute hemolytic anemia. The hemoglobin fell from an average control value of 13.3 grams per cent to as low as 5.4 grams per cent. The mean corpuscular volume rose during the first day of the reaction but thereafter was normal. The mean corpuscular hemoglobin and mean corpuscular hemoglobin concentration were normal throughout. The reticulocytes increased from a control value of 0.2 to 2.1 per cent the day after the reaction and later to 4.5 per cent. The erythrocyte sedimentation rate rose abruptly from 13 to $78 \mathrm{~mm}$. per hour (Westergren). Corrected sedimentation rates (13) indicate that this increase was not due to the anemia alone. There was a leucocytosis of 16,400 per cu. mm. on the second day of the reaction which promptly returned toward normal. There was a definite increase in the "indirect" bilirubin content of the plasma to $3.5 \mathrm{mgm}$. per cent while the "direct" bilirubin did not change. The resistance of the erythrocytes to hypotonic saline showed a slight increase during the reaction but this was probably due to the malaria and not to the pamaquine or anemia (see above, saline fragility). The erythrocyte mechanical fragility exhibited a marked increase from an average control value of 7.3 per cent to 22.9 per cent. Indeed, the morning before the hemolytic anemia began the mechanical fragility had shown a significant increase to 17 per cent. Increase in mechanical fragility does not occur in malaria alone (see above, mechanical fragility).

The per cent of total hemoglobin present as methemoglobin increased to 7.2 , twelve hours before the first evidence of intravascular hemolysis. No methemoglobin could be demonstrated during the next two days, but it reappeared and rose to a value of 10 per cent four days after pamaquine dosage was stopped. It then gradually disappeared. The pigment responsible for the brown discoloration of the plasma just after the hemolytic episode was methemalbumin (8). Hemoglobin and an unidentified pigment with an absorption band between 475 and $500 \mu$ were found in the black urine voided after the reaction. The urine contained no methemoglobin or methemalbumin.

The patient's blood group was $A B$ ( $R h$ positive, subgroup O) 5 and, therefore, there were no isoagglutinins in his serum. There was a slight increase in the cold agglutinin titer after the hemolytic episode. No cold agglutinins were demonstrated before or on the first day of the reaction but the titer was $1: 10$ on the second and $1: 20$ on the fifth day after the episode. Autoagglutination was not present before malaria, but the phenomenon was marked the day following the onset of the hemolytic anemia and before the appearance of cold agglutinins. The intensity of the autoagglutination reaction gradually diminished but still persisted in the fourth week of the follow-up period. The autoagglutination and the presence of cold agglutinins made cross-matching for transfusion difficult. However, good cross-matching was obtained using washed red blood cells and the tube technique at $37^{\circ} \mathrm{C}$.

Serum hemolysins against compatible group $\mathrm{O}$ erythrocytes were not demonstrable. However, incubation of group $O$ erythrocytes for one hour with the patient's serum (obtained the day after the hemolytic reaction) increased the hypotonic saline fragility of the cells to a significantly greater degree than did serum from a normal subject. The erythrocytes showed no tendency to sickle.

The treatment of the anemia in this patient consisted of the oral administration of sodium bicarbonate in large doses to maintain the urine at a high $\mathrm{pH}$. and the giving of two blood transfusions. Quinacrine was given by mouth to control the malaria, even though it is known to decrease the rate of pamaquine degradation.

2. Slowly developing hemolytic anemia. One of the 12 white subjects given $90 \mathrm{mgm}$. of pamaquine base and 2 grams of quinine daily during vivax malaria developed evidence of a mild, slowly developing hemolytic anemia. This represents the only hemolytic anemia observed on this service during administration of pamaquine to 81 white subjects. This patient did not develop signs of hemolytic anemia until the seventh day of pamaquine administration and then the hemoglobin fell gradually from 13.9 to 9.7 grams per cent over a period of six days. Prior to the onset of the signs of hemolytic anemia, this patient had a mean plasma pamaquine level of $198 \mu \mathrm{g}$. per liter, methemoglobin rose to 18.7 per cent of the total hemoglobin, and the resistance of the erythrocytes to hypotonic saline showed a slight but significant decrease. There were no significant changes in the erythrocyte mechanical fragility values.

5 Rh groupings were kindly performed by Dr. A. S. Wiener, Pathology Division, Bellevue Hospital. 


\section{BIBLIOGRAPHY}

1. Brodie, B. B., Udenfriend, S., and Taggart, J. V., The estimation of basic organic compounds in biological fluids. IV. Estimation by coupling with diazonium salts. J. Biol. Chem., 1947, 168, 327.

2. Horecker, B. L., and Brackett, F. S., A rapid spectrophotometric method for the determination of methemoglobin and carbonylhemoglobin in blood. J. Biol. Chem., 1944, 152, 669.

3. Favour, C. B., Autohemagglutinins-"Cold agglutinins." J. Clin. Invest., 1944, 23, 891.

4. Shen, S. C., Castle, W. B., and Fleming, E. M., Experimental and clinical observations on increased mechanical fragility of erythrocytes. Science, 1944, 100, 387.

5. Fischer, O., and Rheindorf, G., Zur Frage der Plasmochin-Nebenwirkung. Arch. Schifft. Tropen. Hyg., 1928, 32, 594.

6. Le Heux, J. W., and von Wyndgaarden, D. C., ther die pharmakologischer Wirkung des Plasmochins. Arch. Exp. Path. Tropen. Hyg., 1929, 144, 341.
7. Hardgrove, M., and Applebaum, I. L., Plasmochin toxicity (in press). Abstr. in Bull. U. S. A. Med. Dept., 1945, 88, 19.

8. Blake, W., Methemalbumin. II. Effect of pamaquine and quinine on pathways of hemoglobin metabolism. J. Clin. Invest., 1948, 27, Suppl., 144.

9. Oliver-Gonzolez, J., Blood agglutinins in blackwater fever. Proc. Soc. Exper. Biol. \& Med., 1944, 57, 25.

10. Hasselmann, C. M., and Hasselmann-Kahlert, M., Erfahrungen und Zwischenfalle bei der Plasmochin Behandlung autochthoner Malaria in den Tropen. Deutsche Med. Wchnschr., 1929, 55, 1635.

11. Schmidt, L. F., Personal communication.

12. Zubrod, C. G., Kennedy, T. J., and Shannon, J. A., Studies on the chemotherapy of the human malarias. VIII. The physiological disposition of pamaquine. J. Clin. Invest., 1948, 27, Suppl., 114:

13. Rourke, M., and Ernstene, A., A method for correcting the erythrocyte sedimentation rate for variations in the cell volume percentage of blood. J. Clin. Invest., 1930, 8, 545. 